\title{
Foreign e-procurement: the case of the Czech economy in the context of employing it professionals
}

\author{
Frantisek Stellner ${ }^{1}$, Radek Sobehart ${ }^{1}$, Stanislav Bilek $^{2,{ }^{*}}$ and Michal Suta ${ }^{3}$ \\ ${ }^{1}$ Department of Economics, Institute of Technology and Business in Ceske Budejovice, Okruzni \\ 517/10, 370 01, Czech Republic \\ ${ }^{2}$ Department of Management, Institute of Technology and Business in Ceske Budejovice, Okruzni \\ 517/10, 370 01, Czech Republic \\ ${ }^{3}$ Faculty of Corporate Strategy, Institute of Technology and Business in Ceske Budejovice, Okruzni \\ 517/10, 370 01, Czech Republic
}

\begin{abstract}
This paper analyses the entry into public tenders within the EU by the Czech companies. This paper investigates which industries have the highest shares of foreign public tenders. This share is compared to the number of hired IT professionals. This paper is based on the thesis that competing in global markets requires skilled labor force in the form of IT specialist. IT specialists (outsourced or employed) can manage electronic supply chain communication and international data interchange. They can integrate systems or adapt them to global opportunities in the public sectors. The dataset is based on the data from the Information and Communication Technologies Questionnaire 2014. The statistical evaluation is based on the probability estimation and detailed summary statistics. Public tenders are a good way for companies from less developed countries because of the lower material and labor costs. The sample of firms is limited to enterprises able to provide goods and services to the public sector. Results suggest that there are differences between industries (services, trade, manufacturing) in the foreign e-procurement and the number of IT workers depend positively on the participation in foreign eprocurement.
\end{abstract}

\section{Introduction}

This paper deals with the global issue of public procurements. Public tenders are a good way to enter the global competition especially in Information and Communication Technologies (ICT) and other branches of industries. Some of the tenders are aimed at innovations (basic and applied research activities). Edquist and Zabala-Iturriagagoitia [2] and Vokoun [7] defined a new term public procurement of innovations and also illustrated its main stages. There is a global public support of research and development (R\&D) activities. This opportunity to enter public tenders is aimed not only at medium-tech and high-tech firms. To enter the e-procurement procedure in foreign country there are certain

* Corresponding author: stanislav.bilek@mail.vstecb.cz 
natural barriers. Kanat et al. [5] used a dataset consisting of the proprietary global online labour market data combined with several publicly available sources of archive data to identify the key determinants of providers' survival to detect the basic mechanisms.Successful and healthy labour market depends on the survival and success of the market participants, and on the sound offer of highly qualified labour force. Some of the electronic public tenders require a national branch office and tenders are written in a foreign language. But the most challenging issue is the work with electronic content and eprocurement interfaces. This goal of this paper is to analyse the characteristics of firms entering public tenders in global markets and the context of employing the information technology (IT) professionals.

This paper follows the research and analysis of e-procurement in European countries and focuses on globalization tendencies. The study [6] recommends having a collaborative research between universities and business community in order to enhance professionality among the contracting authorities to promote effective international purchasing. Such cooperation could go a long way in recommending well-informed solution of practical problems the professionals face in terms of public procurement by means of combining academic workers and experts in industries. Belisari, Appolloni, and Cerruti [11] focus their attention on the Italian market and analyze the positive/negative impacts of adopting eprocurement solutions. The study analyzed two large Italian enterprises which generated approximately 150 e-procurement projects. The authors state that such solutions can impact the enterprise's performance and stress the importance of empirically researching this topic. Also focusing on the Italian market, Dameri et al. [10] aimed their paper at the issues with de/centralizing purchasing in the public sector. Their findings suggest that a hybrid system of purchasing may be ideal - having a centralized central structure with regional center that could address local problems more efficiently. The introduction of new forms of centralized public procurement includes the following: Firstly, the institutional integration of public sector organizations, and secondly, creation of suitable organizational structures within the framework of the state administration services and local communities outside this framework or even outside the public sector with the purpose of effective implementation of public procurement. [1].

Isikdag [14] deals with the topic of e-procurement - in Turkey. He focuses on the construction industry and states that e-procurement generates opportunities for the enhancement of traditional approaches to construction. The study includes a questionnaire survey and interviews, both of which define the fundamental barriers of e-procurement within the construction industry. The results show that there is a lack of trust between the involved parties and that the legal infrastructure is not adequately equipped to deal with the barriers.

Tutu, Kissi, Osei-Tutu, and Desmond [12] analyzed the critical factors of implementing e-procurement in Ghana. The authors point out the benefits of e-procurement (efficiency, cost reduction, standardization of procurement, etc.) and state that the process is still slow in Ghana. The results of their research show that Internet and infrastructure availability, power stability, and capacity enhancement are the critical factors of implementing eprocurement in Ghana.

Czech research into the topic of e-procurement features the study by Hanak [13], which deals with reverse auctions in the public sector. Hanak shows that electronic reverse auctions function successfully if its limitations and principles are respected. Novák, Vokoun, Stellner, Vochozka [15] state that public institutions are key players on regional labor markets in Czechia. They stress the importance of more efficient active and passive employment policies. Mohelska and Sokolova [4] deal with digital transparency in the Czech public sector. The study concludes that Czech municipalities have various degrees of 
digital transparency and that there is a need for a clear legal definition of mandatory disclosure.

This study aims also at the issue of globalization tendencies in the labor market in particular interest in the process of employing (or outsourcing) IT specialist. In their 2018 study, Borghi, Mori, and Semenza [8] focus on the transition of economy to an on-demand economy (knowledge intensive services) in three European countries - UK, Germany, and Italy. They analyzed the transition and point out three questions concerning the labor market: how to legally define the new/adapted professions (like IT specialist); where to place them within the social protection system; how to address the issue of market fragmentation. The results suggest that there are some positive trends of self-employment (and freelancing) in all three countries. Globalization tendencies are pointed out in Anderson and Kovacic [9] study. They focused on competition policy and international trade liberalization. They point out that to ensure good governance in public procurement, integrity of public officials must be ensured and competition must be promoted. They also point out that national competition laws are crucial, including rules for mergers.

\section{Data and method}

Data about ICT activities in 2014 comes from the Czech Statistical Office official survey. The questionnaire contains all kind of questions regarding the use of ICT (Czech Statistical Office [3]). On average, only a fraction (2.8\%) of companies enter the foreign eprocurements. They are mostly oriented at national electronic procurement. The variation coefficients of all variables in Table 1 are quite high.

Table 1. Summary statistics.

\begin{tabular}{|c|c|c|c|c|c|}
\hline Variable & Obs. & Mean & Std. Dev. & Min & Max \\
\hline IT specialists & 6404 & 6.35228 & 62.73171 & 0 & 3800 \\
\hline IT programmers & 6404 & 2.081824 & 15.30953 & 0 & 500 \\
\hline e-procurement & 6404 & 0.249688 & 0.432866 & 0 & 1 \\
\hline Czech e-procurement & 6404 & 0.210181 & 0.407469 & 0 & 1 \\
\hline EU e-procurement & 6404 & 0.02842 & 0.166182 & 0 & 1 \\
\hline No procurement & 6404 & 0.510306 & 0.499933 & 0 & 1 \\
\hline
\end{tabular}

The representativeness of the size classes (Table 2) and industry branches (Table 3) is satisfactory. Most of the observations are form the smaller enterprises with 2 to 29 employees. There are 761 larger enterprises and 288 micro-enterprises. Most of the enterprises are from manufacturing, trade and information services. Other branches are described using NACE classification (The Statistical Classification of Economic Activities in the European Community).

Table 2. Size classes of enterprises.

\begin{tabular}{|c|c|c|c|}
\hline Employees & Obs. & Percent & Cum. \\
\hline Less than 2 & 288 & $4.5 \%$ & $4.5 \%$ \\
\hline 2 to 9 & 2033 & $31.7 \%$ & $36.2 \%$ \\
\hline 10 to 29 & 2225 & $34.7 \%$ & $71.0 \%$ \\
\hline $30-99$ & 1097 & $17.1 \%$ & $88.1 \%$ \\
\hline 100 and more & 761 & $11.9 \%$ & $100.0 \%$ \\
\hline
\end{tabular}

We used classical logit marginal effects to estimate the probability to engage in eprocurement: in general $(0 / 1)$, in national market $(0 / 1)$, and in European market $(0 / 1)$. We 
transformed the variables representing IT specialists and IT Programmers and used asymptotic inverse hyperbolic sine function. Other variables are binary and untransformed. We use this function instead of natural logarithm function because the number of specialists was zero in some of the enterprises. After the estimation we tested the stability of models. The Pearson $\chi^{2}$ goodness of fit test served as postestimation procedure to evaluate whether the model fits the observed data accurately or not. The baseline company for marginal effects is not completely reasonable but we can say that it comes from manufacturing industry and is a microenterprise.

Table 3. Industry branches.

\begin{tabular}{|c|c|c|}
\hline Industry & Freq. & Percent \\
\hline C (Manufacturing) & 2339 & $36.52 \%$ \\
\hline D+E (Utility Supply) & 219 & $3.42 \%$ \\
\hline F (Construction) & 268 & $4.18 \%$ \\
\hline G (Trade) & 970 & $15.15 \%$ \\
\hline H (Transportation and Storage) & 341 & $5.32 \%$ \\
\hline I (Accommodation and Food) & 466 & $7.28 \%$ \\
\hline J (Information Services) & 596 & $9.31 \%$ \\
\hline K (Financial Activities) & 265 & $4.14 \%$ \\
\hline L (Real Estate Activities) & 194 & $3.03 \%$ \\
\hline M (Professional Activities) & 273 & $4.26 \%$ \\
\hline N (Administrative Activities) & 473 & $7.39 \%$ \\
\hline
\end{tabular}

\section{Results}

Foreign e-procurement which is a doorway to global markets is more probable in enterprises dealing with professional activities (NACE category M). The probability is higher in larger enterprises with 30 and more employees. The context of IT workers is interesting. The IT industry (NACE J) is less likely to enter European e-procurement competition. The number of IT programmers has no impact on probability to engage in eprocurement in general. The number of IT specialists contributes to e-procurement in general. The probability of EU oriented e-procurement grows with the number of IT specialist (10\% increase of IT specialist contributes to $2.46 \%$ higher EU procurement probability). The lowest probability of e-procurement is in financial services.

Table 4. The e-procurement logit probability.

\begin{tabular}{|l|c|c|c|}
\hline & $(\mathbf{1})$ & $\mathbf{( 2 )}$ & $\mathbf{( 3 )}$ \\
\hline & e-Procurement & Czechia & EU \\
\hline IT specialists (asinh) & $0.139^{* * *}$ & $0.179^{* * *}$ & $0.246^{* * *}$ \\
\hline & $(0.02)$ & $(0.02)$ & $(0.04)$ \\
\hline IT programmers (asinh) & -0.024 & $-0.059^{*}$ & -0.062 \\
\hline & $(0.03)$ & $(0.03)$ & $(0.04)$ \\
\hline D+E (Utility Supply) & $0.766^{* * *}$ & $0.767 * * *$ & -0.024 \\
\hline & $(0.09)$ & $(0.09)$ & $(0.18)$ \\
\hline F (Construction) & $1.170^{* * *}$ & $1.114^{* * *}$ & 0.168 \\
\hline & $(0.08)$ & $(0.08)$ & $(0.15)$ \\
\hline G (Trade) & $0.177^{* * *}$ & $0.263^{* * *}$ & -0.124 \\
\hline & $(0.05)$ & $(0.06)$ & $(0.11)$ \\
\hline H (Transportation and Storage) & 0.070 & 0.057 & -0.190 \\
\hline & $(0.08)$ & $(0.09)$ & $(0.17)$ \\
\hline
\end{tabular}




\begin{tabular}{|l|c|c|c|}
\hline I (Accommodation and Food) & $-0.396^{* * *}$ & $-0.372^{* * *}$ & -0.274 \\
\hline J (Information Services) & $(0.09)$ & $(0.09)$ & $(0.18)$ \\
\hline & $0.217^{* * *}$ & $0.233^{* * *}$ & $-0.417^{* * *}$ \\
\hline K (Financial Activities) & $(0.07)$ & $(0.07)$ & $(0.13)$ \\
\hline & $-0.471^{* * *}$ & $-0.639^{* * *}$ & $-0.918^{* * *}$ \\
\hline L (Real Estate Activities) & $(0.11)$ & $(0.12)$ & $(0.29)$ \\
\hline & -0.171 & -0.156 & \\
\hline M (Professional Activities) & $(0.12)$ & $(0.13)$ & \\
\hline & $0.494^{* * *}$ & $0.497^{* * *}$ & $0.461^{* * *}$ \\
\hline N (Administrative Activities) & $(0.08)$ & $(0.09)$ & $(0.13)$ \\
\hline & $0.258^{* * *}$ & $0.300^{* * *}$ & -0.237 \\
\hline Employees 10-29 & $(0.07)$ & $(0.07)$ & $(0.16)$ \\
\hline & $0.183^{* * *}$ & $0.168^{* * *}$ & $0.164^{*}$ \\
\hline Employees 30 - 99 & $(0.04)$ & $(0.05)$ & $(0.09)$ \\
\hline & $0.283^{* * *}$ & $0.299^{* * *}$ & $0.338^{* * *}$ \\
\hline Employees 100 and more & $(0.05)$ & $(0.06)$ & $(0.10)$ \\
\hline & $0.256^{* * *}$ & $0.227^{* * *}$ & $0.354^{* * *}$ \\
\hline Constant & $(0.06)$ & $(0.07)$ & $(0.12)$ \\
\hline & $-1.085^{* * *}$ & $-1.257^{* * *}$ & $-2.259^{* * *}$ \\
\hline Observations & $(0.04)$ & $(0.04)$ & $(0.08)$ \\
\hline Goodness of fit test - $\chi 2$ & 6404 & 6404 & 6210 \\
\hline Pseudo R & 1131.73 & 1152.84 & 1152.84 \\
\hline Robust standard errors in parentheses, & $* p 0.10, * * p<0.05, * * * p<0.01$ \\
& & & \\
\hline & 0.0767 & 0.0835 & 0.0835 \\
\hline
\end{tabular}

\section{Conclusion}

Public tenders represent a substantial global market opportunity for all kind if enterprises. The case of the Czech economy showed that larger companies are more likely to engage European electronic procurements. This requires IT workers; however, not highly qualified like programmers but IT specialists who has intermediate digital literacy.

The Czech case study suggest that enterprises representing professional activities (NACE M) are more likely to compete in global e-procurement activities because they were more likely to enter European competition in public tenders. This industry consists of legal and accounting activities, management consultancy activities, architectural and engineering activities, technical testing and analysis, R\&D activities, advertising and market research, translations and other activities.

Only a small fraction of the Czech companies enters the global market for public tenders. The globalization tendencies can help international competition to increase the multinational presence in procurements. Development of information systems and technologies contributed only a little in the field of public contracting. The implementation of e-government systems is slow. Recent electronic procurements provided higher transparency and contributed to the higher multinational enterprises presence.

\section{Acknowledgment}

This paper was created at the Institute of Technology and Business in České Budějovice during the project „8110-006 -Inovace předmětu Základy podnikového práva $\mathrm{v}$ kontextu změn na trhu práce v České republice a Evropské unii“ (Innovation of the course Basics of Commercional Law in the Context of Changes in the Labor Market in the Czech Republic and the European Union). 


\section{References}

1. B. Brezovnik, Z. J. Oplotnik, B. Vojinovic, (De)centralization of public procurement at the local level in the EU. TRANSYLVANIAN REVIEW OF ADMINISTRATIVE SCIENCES 46E, 37-52 (2015)

2. C. Edquist, J. M. Zabala-Iturriagagoitia, Public Procurement for Innovation as mission-oriented innovation policy. RESEARCH POLICY 41, 1757-1769, (2012)

3. CZSO. ICT Questionnaire. Data from Internal Database of Czech Statistical Office. Praha: Czech Statistical Office (2015)

4. H. Mohelska, M. Sokolova, Digital transparency in the public sector - case study Czech Republic. E \& M EKONOMIE A MANAGEMENT 20, 236-250 (2017)

5. I. Kanat, Y. Hong, T. S. Raghu, Surviving in Global Online Labor Markets for IT Services: A Geo-Economic Analysis. INFORMATION SYSTEMS RESEARCH 29, 893909 (2018)

6. M. Tukuta, F. Saruchera, Challenges facing procurement professionals in developing economies: Unlocking value through professional international purchasing. JOURNAL OF TRANSPORT AND SUPPLY CHAIN MANAGEMENT 9 (2015)

7. M. Vokoun, Innovation behaviour of firms in a small open economy: the case of the Czech manufacturing industry. Empirica, 43, 111-139 (2016)

8. P. Borghi, A. Mori, R. Semenza, Self-employed professionals in the European labour market. A comparison between Italy, Germany and the UK. TRANSFER-EUROPEAN REVIEW OF LABOUR AND RESEARCH, 24, 405-419 (2018)

9. R. D. Anderson, W. E. Kovacic, Competition Policy and International Trade Liberalisation: Essential Complements to Ensure Good Performance in Public Procurement Markets. PPLR 18, 67-101 (2009)

10. R. P. Dameri, et al., Centralization vs. Decentralization of Purchasing in the Public Sector: The Role of e-Procurement in the Italian Case. CONTEMPORARY RESEARCH ON E-BUSINESS TECHNOLOGY AND STRATEGY 332, 457-+ (2012)

11. S. Belisari, A. Appolloni, C. Cerruti, Positive and negative impacts of the adoption of e-procurement solutions: The Italian market case. International Journal of Procurement Management 12, 219-241 (2019)

12. S. O. Tutu, E. Kissi, E. Osei-Tutu, A. Desmond, Evaluating critical factors for the implementation of e-procurement in Ghana. International Journal of Procurement Management 12, 1-14 (2019)

13. T. Hanak, Electronic Reverse Auctions in Public Sector Construction Procurement: Case Study of Czech Buyers and Suppliers. TEM JOURNAL-TECHNOLOGY EDUCATION MANAGEMENT INFORMATICS 7, 41-52 (2018)

14. U. Isikdag, An evaluation of barriers to E-Procurement in Turkish construction industry. International Journal of Innovative Technology and Exploring Engineering 8, 252-259 (2019)

15. V. Novak, M. Vokoun, F. Stellner, M. Vochozka, Institutional analysis of contemporary regional labour market in the Czech Republic. E\& M EKONOMIE A MANAGEMENT 19, 4-19 (2016) 